\title{
STUDENTS DISINTEREST IN PHYSICAL EDUCATION CLASSES BY THE LIGHT OF LITERATURE
}

\section{REVIEW ARTICLE}

ANISZEWSKI, Ellen ${ }^{1}$, CELY, Elizangela ${ }^{2}$

Revista Científica Multidisciplinar Núcleo do Conhecimento. Students disinterest in physical education classes by the light of literature. Year 06, Ed. 05, Vol. 08, pp. 69-80. May 2021. ISSN: 2448-0959, Access link in: https://www.nucleodoconhecimento.com.br/education/students-disinterest, $\quad$ DOI: 10.32749/nucleodoconhecimento.com.br/education/students-disinterest

\section{ABSTRACT}

One of the goals of physical education as a mandatory curricular component of basic education is to train motivated individuals and adhere to body practices, relating them with pleasure, thus developing positive attitudes towards them. The literature presents studies with different methodologies and theoretical frameworks to address students' lack of interest in physical education classes. In general, the approach of the theme in high school prevails, because in the light of scientific evidence until then, it constituted the level of education in which disinterest was accentuated and was effectively more evident in extension and intensity, that is, it occurs in several realities and consistently. This article aimed to list the reasons for students' lack of interest in physical education classes found in the literature, presenting them in a categorized way. It was a bibliographic research, of a qualitative nature in which a narrative literature review was chosen. Analyzing the results of research that looked

\footnotetext{
${ }^{1}$ Master in Education.

${ }^{2}$ Master in Education.
}

RC: 85060

Disponível em: https://www.nucleodoconhecimento.com.br/education/students-disinterest 
at the theme, common reasons are identified that lead students to avoid participating in physical education classes, which in general refer to past experiences, the curricular development of the discipline, and socio-demographic issues, the perception of skill / competence, social relations and school management and structure. The contribution of this article is in the possibility of guiding teachers in the elaboration of didactic-pedagogical teaching strategies that contemplate the issues that positively influence students' engagement, participation, and learning.

Keywords: School Physical Education, Motivation, Demotivation.

\section{INTRODUCTION}

To understand the disinterest in Physical Education (PE) classes as a problem, it is assumed that the objectives of school PE are linked to the introduction and integration of the student in the corporal culture of movement, so that he can reproduce and transform - it throughout life (BETTI; ZULIANI, 2002). In addition, PE classes should, in the long run, be motivated and adhered to body practices, relating them with pleasure, thus developing positive attitudes to physical activities and body culture of the movement.

Thus, the motor skills and physical abilities developed in PE classes are some of the aspects that will allow students to become active and discerning individuals about the quality of corporal practices existing in society, relating them to well-being and quality of life.

The literature presents studies with different methodologies and theoretical frameworks to address students' disinterest in PE classes. In general, the approach of the theme in high school prevails, because in the light of scientific evidence until then, it constituted the level of education in which the student's lack of interest was accentuated and was actually more evident in extension and intensity, that is, it

RC: 85060

Disponível em: https://www.nucleodoconhecimento.com.br/education/students-disinterest 
occurs in diverse realities and consistently. This article aimed to systematize the reasons for students' lack of interest in PE classes in the light of literature.

\section{METHODOLOGICAL PROCEDURES}

It was a qualitative bibliographic research in which a narrative literature review was chosen. Articles published between 2010 and 2018 were searched in journals indexed in databases related to the areas of health sciences, education, psychology and interdisciplinary, given the interface of PE with both the humanities and the biological and / or areas of health.

In addition to the publications identified in the period that comprised the bibliographic survey, articles were selected that appeared in the bibliographies of these publications and that addressed the theme and problem of this research, even though they were published outside the period included in the literature survey. The adoption of this criterion was justified because we believe it is important to consider the publications involved with the national context and related to our research problem, as they announce the principle of concerns about student disinterest in PE in elementary school.

\section{PRESENTATION AND DISCUSSION OF RESULTS}

In addition to the publications identified in the period that comprised the bibliographic survey, articles were selected that appeared in the bibliographies of these publications and that addressed the theme and problem of this research, even though they were published outside the period included in the literature survey. The adoption of this criterion was justified because we believe it is important to consider the publications involved with the national context and related to our research problem, as they announce the principle of concerns about student disinterest in PE in elementary school.

RC: 85060

Disponível em: https://www.nucleodoconhecimento.com.br/education/students-disinterest 
Chart 1. Categories and summary of the causes of student demotivation in Physical Education at School.

\begin{tabular}{|c|c|}
\hline Category of causes & Synthesis \\
\hline Past Experiences & $\begin{array}{l}\text { Experiences in physical education classes at } \\
\text { previous levels; }\end{array}$ \\
\hline $\begin{array}{l}\text { Curricular Development of the } \\
\text { discipline }\end{array}$ & $\begin{array}{l}\text { Absence of systematization of content; } \\
\text { Emphasis on procedural vs. conceptual } \\
\text { aspects; } \\
\text { - Students' lack of autonomy. }\end{array}$ \\
\hline Socio-demographic aspects & $\begin{array}{l}\text { School dropout; } \\
\text { Family structure; } \\
\text {. Insertion in the labor market. }\end{array}$ \\
\hline $\begin{array}{l}\text { Perception of Ability } \\
\text { Competence }\end{array}$ & $\begin{array}{l}\text { - Personal beliefs about physical and motor } \\
\text { performance. }\end{array}$ \\
\hline Social Relations and Links & $\begin{array}{l}\text { Teacher-student relationship; } \\
\text {. Relationship with peers (student-student); } \\
\text { Bullying; }\end{array}$ \\
\hline $\begin{array}{l}\text { School Management and } \\
\text { Structure }\end{array}$ & $\begin{array}{l}\text { Class timetable; } \\
\text { Space and physical structure; } \\
\text {. Material available }\end{array}$ \\
\hline
\end{tabular}

Source: the authors

RC: 85060

Disponível em: https://www.nucleodoconhecimento.com.br/education/students-disinterest 


\section{PAST EXPERIENCES}

The students' past personal experiences are presented as one of the determining factors of participation or abstention in activities, since experiences marked by a sense of success and pleasure, in PE classes, will culminate in students more likely to participate in classes (DARIDO, 2004). On the other hand, if previous personal experiences are marked by the feeling of failure, displeasure and exclusion, the option will probably be resistance to participation in classes. (NETO et al., 2010).

Previous personal experiences may be related to the level of skill, inasmuch as the negative feeling of fear of making mistakes becomes decisive for the absence from classes. As a result, students with high ability are seven times more likely to be satisfied with PE classes than students with low skills, as previous experiences provide the incorporation of skills, a key factor for satisfaction with PE classes (BRANDOLIN; KOSLINSKI; SOARES, 2015).

In this perspective, the experiences provided in PE classes, especially in the early years of elementary school, are a determining factor for forming students' opinions about the discipline with regard to learning opportunities, the development of motor skills, the relationship teacher-student as well as the relationship between peers aspects that are related to the motivation to participate in classes. It is also important to reflect on the extent to which the way in which EF has been developed from the most elementary levels of basic education denotes a commitment to the development of basic motor skills, even though we admit that it is not exclusively an opportunity to learn.

Another aspect to be considered is how the experiences in PE classes determine the view on discipline throughout life, as parents, responsible for young people, are based on their past personal experiences to support their children's desire to be exempt from classes. from EF (LAMB, 2014)

RC: 85060

Disponível em: https://www.nucleodoconhecimento.com.br/education/students-disinterest 


\section{CURRICULAR DEVELOPMENT OF THE DISCIPLINE}

Research shows that the selection, treatment and form of development of curricular contents of school EF contribute to the incidence of students' lack of interest in the discipline.

In Brazilian context, the selection of content for PE classes at the various levels of basic education is conditioned by federal documents - whether with a guiding function (National Curriculum Parameters - PCNs - Brazil) or standardization as proposed by the BNCC (Common National Curriculum Base - Brazil), as well as the curricular proposals of the State and Municipal education systems. The BNCC, in the process of being implemented by the federal government, foresees, as knowledge of $\mathrm{PE}$, the corporal practices expressed in the manifestations of the corporal culture of Play and Games, Sports, Dance, Gymnastics, Fights and corporal practices of adventure (BRASIL, 2018).

Systematization refers to the organization and structuring of the discipline's knowledge in a logical order of diversification and deepening of the contents, in order to provide reflection on practice, better planning of activities and better learning conditions. In other words, systematizing the contents of school PE understands its didactic-pedagogical approach in a coherent way at the different levels of education (KAWASHIMA; SOUZA; FERREIRA, 2009).

One of the causes for students' lack of interest in PE classes, and even dropping out of classes, is reflected in the successive repetition of content since elementary school. This is partly due to the students' clear preference for traditional sports stimulated by the media, as well as the fact that teachers circumscribe the development of the curriculum to these contents and, fundamentally, on the procedural level.

RC: 85060

Disponível em: https://www.nucleodoconhecimento.com.br/education/students-disinterest 
Although students frequently express their preference for traditional sports (especially soccer and volleyball), they also express that it would be motivating in classes to be able to choose other modalities as content for classes (CARDOSO; RICARDO; NUNEZ, 2014). The repetition of activities in classes throughout the school years makes PE boring and without purpose for their lives, making it difficult to establish a relationship between the knowledge proposed in classes and its applicability on a permanent basis, making the meaninglessness clear of the activities developed in the classes (SPENCER-CAVALIERE; RINTOUL, 2012).

As a strategy to alleviate this problem, it is suggested the development of other body culture contents, in order to provide students' awareness of the possibility of multiple and diverse experiences of contents provided for in the curriculum. In addition, the need to implement conceptual content in PE is often addressed in academia, however, there is still a lack of consensus in the area on which content to select to be incorporated into the discipline's curriculum.

\section{SOCIO-DEMOGRAPHIC ISSUES}

Sociodemographic issues directly influence the student's school life and can culminate in school dropout (FREITAG, 2007). In this sense, school dropout needs to be considered in its relationship with family structure, entering the job market, interpersonal relationships and the school context.

In an article about school dropout and lack of interest in PE classes, Neto et al. (2010) establish relationships between these two phenomena and state that "The social and cultural aspects have a major impact on the ways of determining school dropout and disinterest" (NETO et al., 2010, p.7). For the authors, there are internal and external factors to the school environment that lead to dropout, and disinterest in certain subjects is one of them. However, in PE classes, the lack of interest reflected in abstaining from participation in activities is more explicit because of its visibility and

RC: 85060

Disponível em: https://www.nucleodoconhecimento.com.br/education/students-disinterest 
practicality, than in other disciplines. In this sense, investigating students' lack of interest in PE classes can contribute to the understanding of factors internal to the school that lead to school dropout.

\section{PERCEPTION OF SKILL AND COMPETENCE}

The processes of inclusion and exclusion in PE classes are usually related to the physical-motor performance of students, because, like the competitive emphasis that often dominates PE classes, makes them crucial for inclusion or exclusion in classes (BRITO; SANTOS, 2013). Furthermore, the literature points out that the situations of displeasure caused by low performance took students away from PE classes, as students with low perceived ability are usually characterized as less active, denote a negative attitude towards PE and a low level of motor commitment (HENRIQUE; JANUÁRIO, 2005).

Another construct observed to influence the withdrawal of students in physical education classes, refers to the concept of alienation based on the low perception of ability to perform activities. As a complement, the powerlessness construct, which concerns the perception of competence / ability and lack of control over what happens in classes, also constitutes a reason for the absence from classes (SPENCER-CAVALIERE; RINTOUL, 2012).

\section{SOCIAL RELATIONSHIPS}

Although the perception of skill / competence has its own characteristics as a factor for taking classes away, this aspect is often associated with the social relationships that are established in PE classes. The withdrawal of some students from PE classes negatively influences others, who can follow the behavior of those who are out of the class, therefore, confirming that actions that stimulate the feeling of security and belonging to the group are possibilities to mitigate the withdrawal from classes. In

RC: 85060

Disponível em: https://www.nucleodoconhecimento.com.br/education/students-disinterest 
another study, authors report that students attached great importance to the presence of friends during activities, showing that the participation of colleagues is a crucial factor for adherence to activities (TENÓRIO; SILVA, 2015).

The negative attitudes of colleagues, regarding unpleasant comments, jokes, humiliations, or aggressions, whether voluntary or involuntary, constitute one of the main reasons for the absence from classes (PAIANO, 2006).

The social dynamics related to the processes of exclusion in the team division in PE classes include the popularity and the level of competence for each student's sport (GRIMMINGER, 2014), in which students, of both sexes, considered less popular, are chosen last. It is worth mentioning that, among boys, popularity is directly related to motor skills, while among girls it is related to other factors, such as family socioeconomic condition and physical appearance.

To the extent that the relationship between participation or non-participation in physical education classes and the interaction between students is considered, as well as the values they attribute to the discipline, it is clear that the social aspects of the classes overlap even with related issues to skill and competence, in which a very skilled student, but with "difficulty" in social relations is more likely to be excluded from the activity than a less skilled student, but very well connected with classmates (MUNK; AGERGAARD, 2015 ).

Another aspect of social relations that has been observed in recent studies is bullying (JACHYRA, 2016; VIANNA; REIS; SOUZA, 2015), in this research, defined as behaviors with different levels of violence, intentional and repetitive (MALTA et al., 2010), as one of the reasons for leaving PE classes. In this context, the study by Jachyra (2016) reported that young men are developing an aversion to PE classes, attributing the withdrawal to frequent experiences of symbolic abuse and humiliation. In this case, bullying falls on students who do not fit the masculine, athletic and

RC: 85060

Disponível em: https://www.nucleodoconhecimento.com.br/education/students-disinterest 
skillful standards required to meet the meritocratic and competitive structure in which they are inserted.

In this sense, the teacher's social support during PE classes becomes essential, given that low levels of teacher social support are related to the motivation that is associated with absenteeism, low participation in classes and low level of physical activity. extra class (MAZYARI et al., 2012).

The school environment almost always reproduces the existing tensions in society and more specifically in the communities where they are inserted, a context that directly interferes in educational practice (RYAN; DECI, 2000). Therefore, it is important to emphasize the importance of the teacher's role in self-regulating students' social behavior and the search for a pedagogical practice that aims to meet the basic psychological needs of students, increasing self-esteem and motivation to participate in activities developed in class.

\section{SCHOOL STRUCTURE AND MANAGEMENT}

Research about the reasons that lead students away from PE classes also brings to light the discussion on issues related to school structure and management. PE classes held outside the normal shift of the other curricular components, lack of an appropriate place for personal hygiene after classes are reasons listed by the students for their absence from classes (SILVA; SILVA; PAULA, 2016; ŠTEMBERGER, 2014).

In view of this, participation in classes is restricted by structural issues of the school, such as lack of accessible spaces, lack of sports gymnasium, lack of safe spaces for practice, lack of materials and equipment and, in addition to these aspects, classes with many students and little attention from the management team to EF (MEHMETI, 2015).

RC: 85060

Disponível em: https://www.nucleodoconhecimento.com.br/education/students-disinterest 


\section{CONCLUSIONS}

From the results of this research, it was realized that the student's lack of interest denotes being related to practices developed at school in general, and that the lack of interest is related to the environment in which the educational process is developed. In PE, disinterest usually culminates in withdrawal from classes, making it something clearly identified, unlike other curricular components in which activities take place in circumscribed spaces and disengagement in classes is less perceived (NETO et al., 2010).

Although the lack of interest in PE classes is widely addressed in the literature, few studies present suggestions to guide teacher's didactic-pedagogical practices, restricting only to the approach on the influence of the motivational climate of the classes and the teacher's posture, often without contextualizing the environment practice.

The contribution of this article is in the approach on the reasons found in the literature about the withdrawal of students from PE classes, systematizing them in order to facilitate guidance in the elaboration of teaching strategies that contribute to overcoming the factors that influence engagement and student participation in teaching activities. Following this logic, we suggest pedagogical practices aimed at satisfying the basic psychological needs of students (ANISZEWSKI et al., 2019), that in the scope of self-determination theory, it means meeting the level of competence of the students - adjusting the activity levels according to the motor development; students' autonomy in classes - making it possible for students to participate in decision-making, in addition to making them aware of the need to develop "selfmanagement" in school life; and the social bonds established in class - in which the teacher turns the interactions with himself and with peers in a positive way, intervening critically in situations involving bullying or any type of prejudice or

RC: 85060

Disponível em: https://www.nucleodoconhecimento.com.br/education/students-disinterest 
discrimination that provides negative experiences and experiences in the context of the teaching-learning.

\section{REFERENCES}

ANISZEWSKI, E. et al. (A)Motivation in physical education classes and satisfaction of competence, autonomy and relatedness. Journal of Physical Education, v. 30, n. e3052, p. 1-11, 2019. Doi.org/10.4025/jphyseduc.v30i1.3052

BETTI, M.; ZULIANI, L. R. Educação Física Escolar: uma proposta de diretrizes pedagógicas. Revista Mackenzie de Educação Física e Esporte, v. 1, n. 1, p. 73$81,2002$.

BRANDOLIN, F. et al. A percepção dos alunos sobre a educação física no ensino médio. Revista da Educação Física/UEM, v. 26, n. 4, p. 601, 2015. Doi: $10.4025 /$ reveducfis.v26i4.29836

BRASIL. Base Nacional Comum Curricular: Ensino Médio. Brasília: MEC/Secretaria de Educação Básica, 2018.

BRITO, L. T. L.O de.; SANTOS, M. P. dos. Masculinidades na Educação Física escolar: um estudo sobre os processos de inclusão / exclusão. Rev Bras Educ Fís Esporte, v. 27, n. 2, p. 235-246, 2013.

CARdoso, A. G.; RICARDO, P.; NUNEZ, M. Percepção dos alunos do ensino médio em relação às aulas de educação fisica. Coleção Pesquisa em Educaçõ Física, v. 13, n. 4, p. 125-132, 2014.

DARIDO, S. C. A educação física na escola e o processo de formação dos não praticantes de atividade física. Revista Brasileira de Educação Física e Esporte, v. 18, n. 1, p. 61-80, 2004. 
FREITAG, B. Escola, Estado e Sociedade. [s.I: s.n.]. 2007.

GRIMMINGER, E. Getting into teams in physical education and exclusion processes among students. Pedagogies: An International Journal, v. 9, n. 2, p. 155-171, 2014. Doi: 10.1080/1554480X.2014.899546

HENRIQUE, J.; JANUÁRIO, C. Students 'self-perception of their ability and perspective about physical education. Motriz., v. 11, p. 37-48, 2005.

JACHYRA, P. Boys, bodies, and bullying in health and physical education class: implications for participation and class: implications for participation and well-being. Asia-Pacific Journal of Health, Sport and Physical Education, v. 7122, n. August, p. 121-138, 2016. Doi: 10.1080/18377122.2016.1196112

KAWASHIMA, L. B.; SOUZA, L. B. DE; FERREIRA, L. A. Sistematização de conteúdos da Educação Física para as séries iniciais. Motriz, v. 15, n. 2, p. 458468, 2009.

LAMB, P. Ritual associated with participation in physical education: The power of excuse notes. European Physical Education Review, v. 20, n. 1, p. 120-139, 2014. Doi: $10.1177 / 1356336 \times 13496005$

MALTA, D. C. et al. Bullying nas escolas brasileiras: resultados da Pesquisa Nacional de Saúde do Escolar. Ciência \& Saúde Coletiva, v. 15, n. 2, p. 3065 3076, 2010.

MAZYARI, M. et al. Students' amotivation in physical education activities and teachers' social support. World Applied Sciences Journal, v. 20, n. 11, p. 1570 1573, 2012. Doi: 10.5829/idosi.wasj.2012.20.11.1716

MEHMETI, I. Motivational level and participation barriers in school physical education among adolescents. SportMont, n. 43-45, p. 121-126, 2015.

RC: 85060

Disponível em: https://www.nucleodoconhecimento.com.br/education/students-disinterest 
MUNK, M.; AGERGAARD, S. The Processes of Inclusion and Exclusion in Physical Education: A Social-Relational Perspective. Social Inclusion, v. 3, n. 3, p. $67-81,2015$. Doi: 10.17645/si.v3i3.201

NETO, A. R. M. et al. Evasão escolar e desinteresse dos alunos nas aulas de educação física. Pensar a prática, v. 13, n. 2, p. 1-15, 2010.

PAIANO, R. Possibilidades de orientação da prática pedagógica do profesor de educaçao física: situações de desprazer na opinião dos alunos. Revista Mackenzie de Educacao Fisica e Esporte, v. 5, n. 1, p. 47-57, 2006.

RYAN, R.; DECl, E. Self-determination theory and the facilitation of intrinsic motivation. American Psychologist, v. 55, n. 1, p. 68-78, 2000.

SILVA, F. C. de S.; et al. Caracterização dos estudantes de ensino médio quanto à não participação das aulas de educação física escolar em escolas de um município de médio porte no interior do Ceará. Conexões, v. 14, n. 1983-9030, p. 35-52, 2016. Doi:10.20396/conex.v14i1.8644765

SPENCER-CAVALIERE, N.; RINTOUL, M. A. Alienation in Physical Education From the Perspectives of Children. Journal of Teaching in Physical Education, v. 31, n. 4, p. 344-361, 2012.

ŠTEMBERGER, V. Excuses in physical education made by primary school pupils of fourth and fifth class. Acta universitatis carolinae kinanthropologica, v. 50, p. 15-28, 2014.

TENÓRIO, J. G.; SILVA, C. L. da. O desinteresse dos estudantes pelas aulas de educação física em uma escola de ensino público do estado de Mato Grosso. Salusvita, v. 34, p. 27-44, 2015. 
VIANNA, J. A.; REIS, K. P. DOS; SOUZA, S. M. de. Bullying nas aulas de Educação Física: a percepção dos alunos no Ensino Médio. Ensaio: aval. pol. públ. Educ., v. 23, n. 86, p. 73-93, 2015.

Sent: March, 2021.

Approved: May, 2021.

RC: 85060

Disponível em: https://www.nucleodoconhecimento.com.br/education/students-disinterest 